Jpn. J. Med. Mycol.

Vol. 49, $119-123,2008$

ISSN $0916-4804$

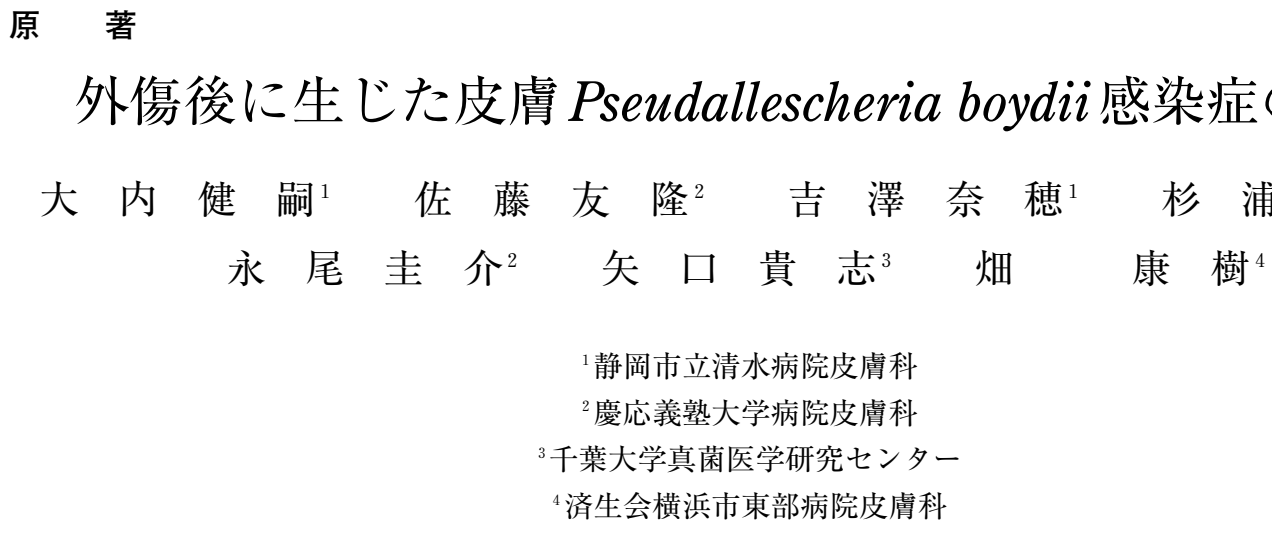

〔受付：9月19日，2007年，受理：1月10日，2008年〕

\begin{abstract}
要 旨
外傷を契機として発症した皮膚Pseudallescheria boydii（P. boydii）感染症の 1 例を経験したので報告した. 79 歳男性. 左乳癌に対する集学的治療後, 放射線性肺炎に対してプレドニゾロン $25 \mathrm{mg}$ /日内服中であった. 左膝 に擦過傷を受傷し， 2 週間後より同部位から排膿を認めるようになった. 初診時, 左膝に長径 $40 \mathrm{~mm}$ の暗赤色 局面を認め, 表面に小びらん形成と黄白色の排膿を認めた。熱感はそしく, 疼痛を軽度訴えていた. 病理組織学 的検査では真皮から皮下組織にかけて肉芽腫を形成し, Grocott染色上，分岐した有隔菌糸が多数，確認された。 ゲノム DNAを抽出後, internal transcribed spacer（ITS）領域を解析し，P. boydii と同定した. イトラコナ ゾール $200 \mathrm{mg}$ /日の内服を 4 週間行ったところ, 病変は痽痕治癒した. P. boydii 感染症は, 検鏡や病理で分岐し た有隔菌糸が観察されるが，形態のみではその他の糸状菌との鑑別が不可能であるため，診断の確定には菌学的 検査が不可欠である. 生体の免疫力低下を伴う基礎疾患の増加に伴い, 今後増加しうる感染症であり, 本菌によ る感染症は抗真菌薬の選択が重要であるため, 正しい診断に基づいた治療を開始することが求められる.
\end{abstract}

Key words： 皮膚Pseudallescheria boydii 感染症 (cutaneous pseudoallescheriasis), Scedosporium apiospermum, イトラコナゾール (itraconazole), 免疫不全患者 (immunocompromised patients)

\section{序文}

Pseudallescheria boydii は子震菌に属する糸状菌で, 土 壤中に広く生息し，シュードアレシェリア症 (pseudoallescheriasis) と呼ばれる感染症の原因菌であ る ${ }^{1)}$. 温帯地域での外傷からの菌腫症がほとんどとされ てきたが, 臓器移植, 白血病, ステロイドや免疫抑制剤 投与中の患者における皮膚ないし内藏病変が 1990 年以 降, 多数報告されている ${ }^{2)}$. 今回我々は, 免疫不全患者 に外傷を契機として発症した皮膚Pseudallescheria boydii 感染症の 1 例を経験したので報告する。

別刷請求先：大内健嗣

干 424-8636 静岡県静岡市清水区宮加三1231

静岡市立清水病院皮虐科
症例

患者：79歳男性（自営業）

主訴：左膝の擦過傷

初診：平成 18 年 10 月中旬

家族歴：特記すべき事なし

既往歴：平成 13 年, 左乳癌に対して手術・化学療法. 平成 15 年，傍胸骨リンパ節転移に放射線療法を施行. 放射線性肺炎に対しステロイドパルス療法後，プレドニ ゾロン $25 \mathrm{mg} /$ 日内服中であった。

現病歴：初診の 2 週間前に病院前の土の上で転倒し, 左膝に擦過傷を受傷. 抗生剂含有軟膏外用で処置を行い, 一度は上皮化傾向を認めたが，同部位から排膿を認める ようになり，当科を初診した。

初診時現症：左膝に長径 $40 \mathrm{~mm}$ の暗赤色局面を認め, 表面に小びらん形成と黄白色の排膿を認めた。熱感はそ しく，疼痛を軽度訴えていた（Fig. 1)。 


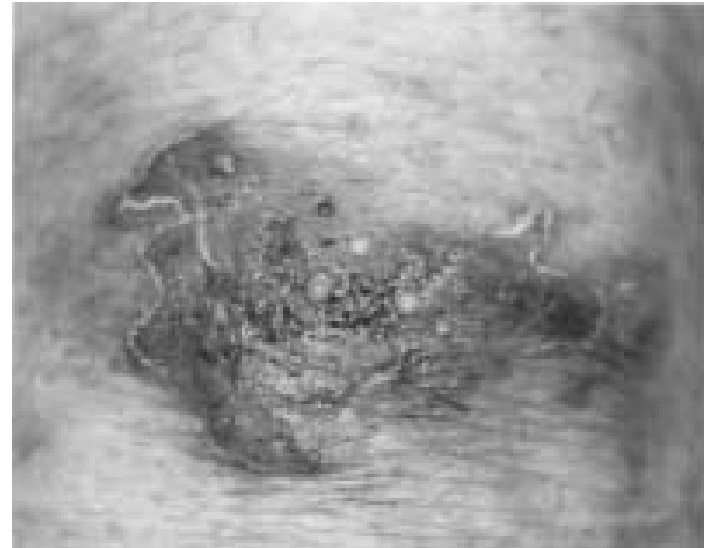

Fig. 1. Dark brown plaque with yellow pus on the left knee.

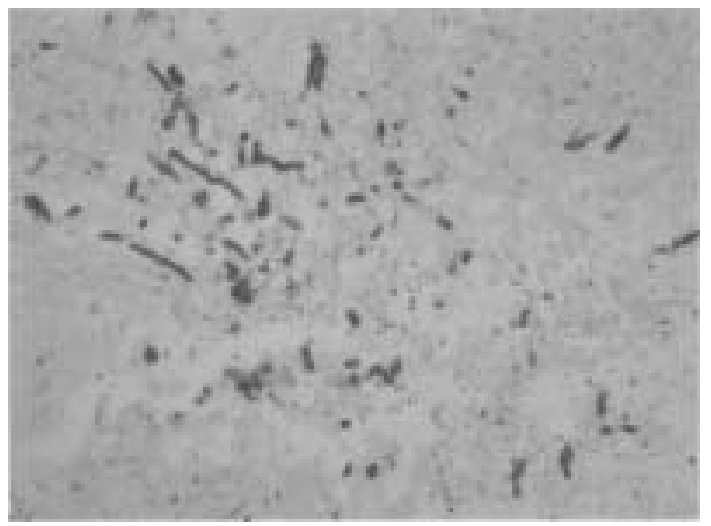

Fig. 3. Abundant bifurcated hyphae. (Grocott-methenamine stain)

病理組織学的検査：真皮から皮下組織に好中球・リン パ球・組織球・巨細胞の稠密な浸潤が見られ肉芽腫を形 成していた（Fig. 2). Grocott染色上，分岐有隔菌糸が 真皮内に確認された（Fig. 3).

菌学的検査：黄色膿の細菌培養は陰性であった。組織

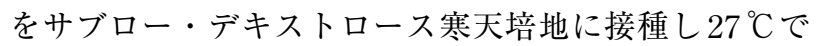
培養したところ表面綿状白色のコロニーを形成した (Fig. 4). 分離株のコーンミール培地でのスライド培養 では分生子柄束を有する Graphium 型, 砲弾型で褐色単 細胞性のScedosporium 型の分生子が見られた（Fig. 5） が，閉子囊殼は認めなかった。ゲノム DNAを抽出し， ユニバーサルプライマー（ITS1, ITS4）を用い約 $600 \mathrm{bp}$ の $5.8 \mathrm{~S}$ rDNAを含む internal transcribed spacer（ITS） 領域を PCR 法で増幅し, DNA シークエンサーを用い塩 基配列を決定した ${ }^{3)}$. NCBI（http://www.ncbi.nlm.nih. gov/blast/）にアクセスし登録されている菌株と相同性 を検討したところ Pseudallescheria boydii（AY 217658.1） と塩基／塩基：517/521（99\%）一致し, Pseudallescheria boydii (IFM 54747) と同定した.

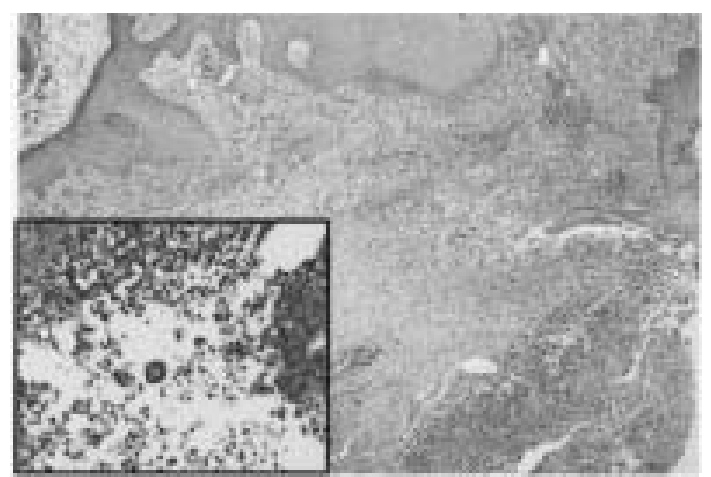

Fig. 2. Granuloma was observed in the dermis. (hematoxylin \& eosin stain)

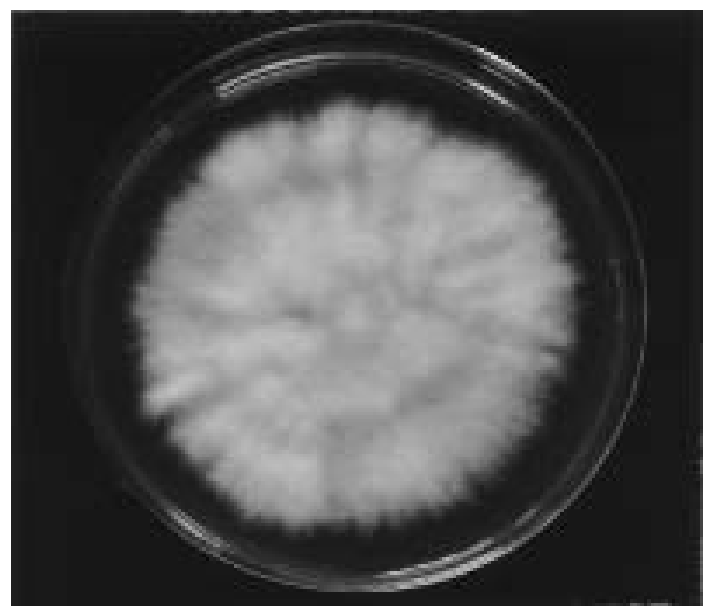

Fig. 4. Colony isolated from affected area was smokywhite in color.

経過：胸部 CT上, 肺病変は認めなかった。皮膚 Pseudallescheria boydii 感染症と診断し, イトラコナゾー ル $200 \mathrm{mg}$ /日の内服を 4 週間行ったところ, 瘢痕治癒し た (Fig. 6).

\section{考察}

Pseudallescheria boydii (P. boydii) は子襄菌類で, 有 性生殖が見られず分生子のみ形成する無性世代はScedosporium apiospermum と呼ばれる. 真菌における命名 法では完全世代の菌名が優先されることから，閉子囊殼 の形成能力を失っている場合でも P. boydii と呼称される ことが一般的である ${ }^{4)}$.

P. boydii は形態学および遺伝子レベルでも多様性があ り，分類途上である。自験例ではGraphium 型とされる 分生子柄束の形成を認め，コーンミールおよびサブロー 培地上では閉子囊殼・子震胞子の形成を認めなかった。 ITS 領域のシークエンス解析上は, 既存のP. boydiiの配 列と一致したことから同菌と同定した．完全世代の形成 がサブロー培地などの一般培養培地で認めることが特徵 

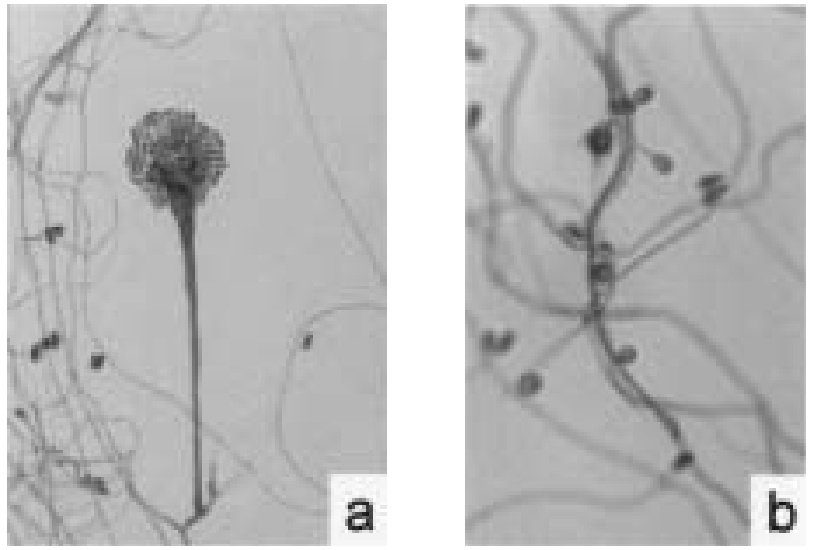

Fig. 5. a. Graphium type conidium, b. Scedosporium type conidium. (Slide culture)

とされるP. boydiiであるが，Graphium 型分生子柄束の 形成される段階では閉子囊殼を形成するもの・しないも のがあり，自験例のように完全世代を認めない株につい ては遺伝子レベルの同定が有用である ${ }^{5)}$.

本菌は環境中に生息し温帯地域での菌腫症の主要な起 因菌とされているが, 時に目, 耳, 中枢神経系, 肺に感 染症を引き起こす。この感染症は空中に浮遊する分生子 の吸入, 貫通性外傷を受けた局所への真菌要素の直接播 種によって起こると考えられている ${ }^{5)}$.

P. boydiiによる皮膚への侵襲性感染は, PUBMEDで 検索した限り 1980 年以降 49 例 ${ }^{6-33}$ 報告され，1990年以 降に報告数が増加し 43 例 $^{6-28)}$ であった。 また，医学中 央雑誌で検索したところ 1980 年以降 12 例 ${ }^{34-45)}$ が報告さ れ，1990年以降に報告数が増加し 11 例 ${ }^{34-44)}$ であった。 総計 60 例のうち海外症例 45 例, 本邦症例は 15 例である. 海外症例の平均年齢は 51 歳, 男女比は約 $2: 1$. 本邦症 例の平均年齢は 65 歳, 男女比は $2: 1$ であった. 国外症 例における発症年齢が低い傾向があったが，これは若年 発症の血液疾患に合併した症例が含まれるためであ る $^{15,17,20)}$.

海外の 45 例中 34 例 6.8,10,11,12,14,15,17-20,22-27) が糖尿病ないし, 自己免疫性疾患や臓器移植後に対する免疫抑制療法中で あり，何らかの免疫不全状態であった。1990年以前は 術創に感染するなど医原性の原因も散見された ${ }^{30.32)}$.ま た，国内の 16 例中 14 例 $34.36 .37 .39-45)$ が自己免疫性疾患 - 糖尿 病・狭心症などの基礎疾患を持ち，うち 12 例 $34.36 .39,40.42-44)$ が副腎皮質ホルモンなどによる免疫抑制療法中であっ た.

免疫不全者に生じた場合の臨床症状は多発性結節 ${ }^{9)}$, 皮下硬結 ${ }^{12)}$ ，リンパ管型スポロトリコーシス様 ${ }^{39,45)}$ など 様々な症状の報告があった。典型的な菌腫症の症例は海 外において 1990 年以前に 2 例 ${ }^{29,30)}$ および 2002 年 ${ }^{16)}$ に 1 例報告があるのみで，本邦では免疫健常者に生じた菌腫 の前段階と考えられる真菌性肉芽腫が報告されている ${ }^{38)}$. 罹患部位に関して，7 例は皮膚に播種性の病変拡大を 認めた ${ }^{6,9,15,17,18,20,26)}$ が，単発型は四肢が主体で半数に罹患

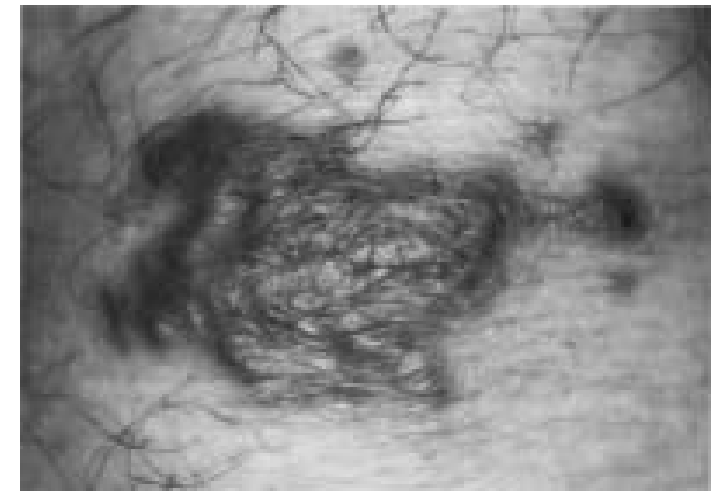

Fig. 6. Hypertrophic scar after treatment.

部位の外傷の既往があったことから，外傷を起点として 真菌の直接播種があったことが推測される．皮膚病変の みの場合, 抗真菌剂・外科的切除で軽快を得られるが, 播種性の場合, 肺や脳などの内臓病変へ進展し予後不良 な例があった ${ }^{15.17)}$.

選択される抗菌薬であるが，ミコナゾール 3 例 ${ }^{32.33 .43)}$, ケトコナゾール 2 例 ${ }^{29,31)}$ ，イトラコナゾール 28 例 ${ }^{9,10,14,16,21,28,38,39)}$ ，アンホテリシン-B 3 例 ${ }^{15,20,24)}$, ボリコナ ゾール 7 例 ${ }^{6-8,15,18,20,34)}$ の記載があった。アンホテリシン-B 投与例のうち 2 例は播種性感染例であったが感受性がな く, ボリコナゾールへ変更されていた ${ }^{15,20)}$.

自験例の分離株に対するイトラコナゾール，ミカファ ンギンナトリウム，ミコナゾールの MIC 值はそれぞれ 0.5, 0.06, $0.25 \mu \mathrm{g} / \mathrm{ml}$ であり, アンホテリシン-B, フル コナゾール，フルシトシンの MIC值はそれぞれ1.0，16， $64 \mu \mathrm{g} / \mathrm{ml}$ であった. 過去の症例, また今回施行した感 受性試験からも, アンホテリシン-Bでなく, イトラコ ナゾールの適応が確認された。日本では 2005 年に発売 が開始されたボリコナゾールは一般に本菌に強い抗菌活 性を有する ${ }^{46)}$ とされ，イトラコナゾール無効例もある ${ }^{34)}$ ことから, ボリコナゾールの上市以降は国内外において 第一選択薬として使用されている ${ }^{6-8,34}$.

皮膚 P. boydii 感染症は, 検鏡や病理で分岐した有隔菌 糸が観察されるが，形態のみではその他の糸状菌との鑑 別が不可能であるため ${ }^{47}$, 診断の確定には菌学的検査が 不可欠である.臓器移植, 骨髄移植, 免疫抑制剂投与な ど生体の免疫力低下を伴う基礎疾患の増加に伴い，今後 増加しうる感染症である．本菌による感染症は抗真菌薬 の選択が重要であるため，正しい診断に基づいた治療を 開始することが求められる. 


\section{文献}

1) O’Bryan TA: Pseudallescheriasis in the 21st century. Expert Rev Anti Infect Ther 3: 765-773, 2005.

2) Castiglioni B, Sutton DA, Rinaldi MG, Fung J, Kusne S: Pseudallescheria boydii (Anamorph Scedosporium apiospermum). Infection in solid organ transplant recipients in a tertiary medical center and review of the literature. Medicine 81: 333-348, 2002.

3) Ouchi T, Nagao K, Hata Y, Otuka T, Inazumi T: Trichophyton tonsurans infection manifesting as multiple concentric annular erythemas. J Dermatol 32: 565-568, 2005.

4) Kwon-Chung KJ, Bennet JE: Psuedallescheriasis and Scedosporium infection. In Medical Mycology (KwonChung KJ, Bennet JE), pp.678-694, Lea \& Febiger, Philadelphia, 1992.

5) Gilgado F, Cano J, Gené J, Guarro J: Molecular phylogeny of the Pseudallescheria boydii species complex: proposal of two new species. J Clin Microbiol 43: 4930-4932, 2005.

6) Rogasi PG, Zanazzi M, Nocentini J, Fantoni E, Trotta M, Faggi E, Fontanelli A, Bertoni E, Salvadori M, Leoncini F: Disseminated Scedosporium apiospermum infection in renal transplant recipient: long-term successful treatment with voriconazole: a case report. Transplant Proc 39: 2033-2035, 2007.

7) Tammer I, Seibold M, Krause H, Tintelnot K, König W, König B: Successful topical therapy with voriconazole: pseudallescheriasis after injury. J Trauma 62: 12951297, 2007.

8) Lainscak M, Hocevar A, Logar D, Beovic B, Matos T, Tomsic M: Subcutaneous infection with Pseudallescheria boydii in an immunocompromised patient. Clin Rheumatol 26: 1023-1024, 2007.

9) Enshaieh SH, Darougheh A, Asilian A, Iraji F, Shahmoradi Z, Yoosephi A, Davami M, Siadat AH, Vaez A: Disseminated subcutaneous nodules caused by Pseudallescheria boydii in an atopic patient. Int J Dermatol 45: 289-291, 2006.

10) Uenotsuchi T, Moroi Y, Urabe K, Tsuji G, Koga T, Matsuda T, Furue M: Cutaneous Scedosporium apiospermum infection in an immunocompromised patient and a review of the literature. Acta Derm Venereol 85: 156159,2005

11) Ahmed J, Ditmars DM, Sheppard T, del Busto R, Venkat KK, Parasuraman R: Recurrence of Scedosporium apiospermum infection following renal re-transplantation. Am J Transplant 4: 1720-1724, 2004.

12) Reimann D, Büssemaker E, Gross P: Successful treatment due to vacuum seal technique of a severe Scedosporium apiospermum skin infection in a renal transplant recipient. Nephrol Dial Transplant 19: 245-248, 2003.

13) Karaarslan A, Arikan S, Karaarslan F, Cetin ES: Skin infection caused by Scedosporium apiospermum. Mycoses 46: 524-526, 2003.

14) Chaveiro MA, Vieira R, Cardoso J, Afonso A: Cutaneous infection due to Scedosporium apiospermum in an immunosuppressed patient. J Eur Acad Dermatol
Venereol 17: 47-49, 2003.

15) Fietz T, Knauf W, Schwartz S, Thiel E: Intramedullary abscess in a patient with disseminated Scedosporium apiospermum infection. Br J Haematol 120: 724, 2003.

16) Horré R, Schumacher G, Marklein G, Stratmann H, Wardelmann E, Gilges S, De Hoog GS, Schaal KP: Mycetoma due to Pseudallescheria boydii and co-isolation of Nocardia abscessus in a patient injured in road accident. Med Mycol 40: 525-527, 2002.

17) Bonduel M, Santos P, Turienzo CF, Chantada G, Paganini H: Atypical skin lesions caused by Curvularia sp. and Pseudallescheria boydii in two patients after allogeneic bone marrow transplantation. Bone Marrow Transplant 27: 1311-1313, 2001.

18) Kusne S, Ariyanayagam-Baksh S, Strollo DC, Abernethy J: Invasive Scedosporium apiospermum infection in a heart transplant recipient presenting with multiple skin nodules and a pulmonary consolidation. Transpl Infect Dis 2: 194-196, 2000.

19) Miyamoto $T$, Sasaoka $R$, Kawaguchi $M$, Ishioka $S$, Inoue T, Yamada N, Mihara M: Scedosporium apiospermum skin infection: a case report and review of the literature. J Am Acad Dermatol 39: 498-500, 1998.

20) Girmenia C, Luzi G, Monaco M, Martino P: Use of voriconazole in treatment of Scedosporium apiospermum infection: case report. J Clin Microbiol 36: 1436-1438, 1998.

21) Liu YF, Zhao XD, Ma CL, Li CX, Zhang TS, Liao WJ: Cutaneous infection by Scedosporium apiospermum and its successful treatment with itraconazole. Clin Exp Dermatol 22: 198-200, 1997.

22) Ichikawa T, Saiki M, Tokunaga S, Saida T: Scedosporium apiospermum skin infection in a patient with nephrotic syndrome. Acta Derm Venereol 77: 172-173, 1997.

23) Ruxin TA, Steck WD, Helm TN, Bergfeld WF, Bolwell BJ: Pseudallescheria boydii in an immunocompromised host. Successful treatment with debridement and itraconazole. Arch Dermatol 132: 382-384, 1996.

24) Cunningham R, Mitchell DC: Amphotericin B responsive Scedosporium apiospermum infection in a patient with acute myeloid leukaemia. J Clin Pathol 49: 93-94, 1996.

25) Török L, Simon G, Csornai A, Tápai M, Török I: Scedosporium apiospermum infection imitating lymphocutaneous sporotrichosis in a patient with myeloblasticmonocytic leukaemia. Br J Dermatol 133: 805-809, 1995.

26) Bernstein EF, Schuster MG, Stieritz DD, Heuman PC, Uitto J: Disseminated cutaneous Pseudallescheria boydii. Br J Dermatol 132: 456-460, 1995.

27) Lopes JO, Alves SH, Benevenga JP, Salla A, Khmohan C, Silva CB: Subcutaneous pseudallescheriasis in a renal transplant recipient. Mycopathologia 125: 153-156, 1994.

28) Pether JV, Jones W, Greatorex FB, Bunting W: Acute pyogenic Pseudallescheria boydii foot infection sequentially treated with miconazole and itraconazole. J Infect 25: 335-336, 1992.

29) Stierstorfer MB, Schwartz BK, McGuire JB, Miller AC: Pseudallescheria boydii mycetoma in northern New Eng- 
land. Int J Dermatol 27: 383-387, 1988.

30) Fernández-Guerrero ML, Ruiz Barnés P, Alés JM: Postcraniotomy mycetoma of the scalp and osteomyelitis due to Pseudallescheria boydii. J Infect Dis 156: 855, 1987.

31) Willsteed E, Regan W: Treatment of Pseudallescheria boydii infection with oral ketoconazole and topical miconazole. Australas J Dermatol 28: 21-23, 1987.

32) Lazarus HS, Myers JP, Brocker RJ: Post-craniotomy wound infection caused by Pseudallescheria boydii. Case report. J Neurosurg 64: 153-154, 1986.

33) Collignon PJ, Macleod C, Packham DR: Miconazole therapy in Pseudallescheria boydii infection. Australas J Dermatol 26: 129-132, 1985.

34）松本由香, 大井綱郎, 永井彩子, 大山文乾, 大石 毅：ボリ コナゾールが奏功したScedosporium apiospermum 感染症 の1例. 日皮会誌 117: 708, 2007.

35）坂 義経：右拇指爪甲下に生じたScedosporium apiospermum 感染症の 1 例. 日本皮膚科学会雑誌. 日皮会誌 116 : 1217, 2006.

36）山下奈美子, 平井都始子, 丸上永晃, 森井多美子：リンパ 管型皮下膿瘍を伴った下肢Scedosporium apiospermum 真 菌感染症の 1 例. 超音波医学 33: 369-370, 2006.

37）武市浩美, 洙田由美子, 荒瀬誠治：Scedosporium apiospermum 感染症の 1例. 医学検査 50: 1568-1572, 2001.

38）野間陽子, 村上信司, 中岡啓喜, 白石 聡, 宮内俊次, 西村 和子, 橋本公二: 免疫学的健常者に生じた皮膚シュード アレシェリア症の1例. 日皮会誌 109: 1341-1346, 1999.

39）神谷美知代, 野田徳朗, 中谷明美：リンパ管型スポロトリ
コーシス様病変を示したPseudallescheria boydiiによる皮 膚真菌症の 1 例. 真菌誌 39: 33-36, 1998.

40）小林裕美, 安永千尋, 古川雅祥, 石井正光, 庄司昭伸, 内田 勝久, 浅井芳江：長期ステロイド内服治療中のSLE患者 に生じたScedosporium apiospermum（テレオモルフ： Pseudallescheria boydii）感染による多発性皮下膿瘍. 日皮 会誌 107: 345, 1999.

41）井上千津子, 倉知貴志郎, 村田葉子. Scedosporium apiospermum の皮膚感染. 皮臨 39: 962-963, 1997.

42）市川 健, 斉木 実, 徳永真一：Scedosporium apiospermum 皮膚感染症の1例. 日皮会誌 107: 1411, 1997.

43）藤崎弘之, 磯八上正明, 滝尻珍重, 橋本公二, 吉川邦彦: Scedosporium apiospermumによる皮膚深在性真菌症の 1 例. 日皮会誌 102: 245, 1992.

44）野田徳朗, 奥村 哲, 鹿野由紀子, 前田 学, 森 俊二, 宇 田川俊一：毛包炎様皮疹を生じたScedosporium apiospermumの皮膚感染例. 日医真菌誌 31: 125, 1990.

45）森田正道, 清水鈴昭, 廣田 豊, 松本修一：リンパ管型ス ポロトリコーシス様の臨床症状を示したScedosporium apiospermum 感染の一例. 医療 41: 610, 1987.

46) Nesky MA, McDougal EC, Peacock Jr JE: Pseudallescheria boydii brain abscess successfully treated with voriconazole and surgical drainage: case report and literature review of central nervous system pseudallescheriasis. Clin Infect Dis 31: 673-677, 2000.

47) Virgili A, Zampino MR, Mantovani L: Fungal skin infections in organ transplant recipients. Am J Clin Dermatol 3: 19-35, 2002.

\title{
A case of Cutaneous Pseudallescheria boydii infection caused by Trauma
}

\author{
Takeshi Ouchi ${ }^{1}$, Tomotaka Sato ${ }^{2}$, Naho Yoshizawa ${ }^{1}$, Makoto Sugiura ${ }^{1}$, \\ Keisuke Nagao ${ }^{2}$, Takashi Yaguchi ${ }^{3}$, Yasuki Hata ${ }^{4}$ \\ ${ }^{1}$ Shizuoka Municipal Shimizu Hosipital, 1231 Miyakami, Shimizu-ku, Shizuoka 420-8636, Japan \\ ${ }^{2}$ Department of Dermatology, Keio University Hospital, 35 Shinanomati, Shinjyuku-ku, Tokyo 160-8582, Japan \\ ${ }^{3}$ Medical Mycology Research Center, Chiba University, 1-8-1 Inohana, \\ Chuo-ku, Chiba 260-8673, Japan \\ ${ }^{4}$ Saiseikai Yokohamashi Toubu Hospital, 3-6-1 Sueyoshi Turumi-ku, Kanagawa, 230-0012, Japan
}

\begin{abstract}
Pseudallescheria boydii is a ubiquitous filamentous fungus. We report a case of cutaneous $P$. boydii infection of the left knee in a 79-year-old Japanese man who was receiving oral predonisolone $(25 \mathrm{mg} /$ day $)$ for radiation pneumonitis after radiation therapy on left breast cancer. He presented with a 2-week-history of a lesion on the left knee. A biopsy specimen from the skin lesion revealed granulomatous inflammation with hyphae. Culture of the pus from the skin specimen confirmed the diagnosis of cutaneous $P$. boydii infection. rDNA ITS sequence was analyzed to confirm the mycological diagnosis. The patient was treated orally with $200 \mathrm{mg}$ /day of itraconazole. The lesion was gradually cured and left a hypertrophic scar. Cutaneous injury may be responsible for an incidence of localized infection. Such rare fungus infection in immunocompromised patients who have a persistent traumatic skin ulcer needs to be ruled out. An opportunistic infection in immunocompromised patients can be life-threatening and prompt treatment based on accurate diagnosis is important.
\end{abstract}

